\title{
The Legitimation Strategies of "Progressive" Prosecutors
}

\author{
Alexandra L Cox \\ University of Essex, UK \\ Camila Gripp \\ The Justice Collaboratory, Yale Law School, USA
}

\begin{abstract}
This article focuses on the self-legitimation strategies of frontline prosecutors working in a Northeastern city in the United States ("Belton”). The research took place in a selfdescribed "progressive" prosecutor's office in the midst of a legitimacy crisis that prosecutors faced across the country. The prosecutors in Belton spoke about their role and practices in the face of this legitimacy crisis through a strategy of differentiation from other criminal justice actors, aimed at establishing their purported positional and moral superiority in enacting criminal justice practices, and through minimizing their responsibility for the systemic harms that prosecutors more generally have been said to perpetuate.
\end{abstract}

\section{Keywords}

Self-legitimacy, legitimation, prosecutors, mass incarceration, procedural justice

\section{Introduction}

The study of legitimation discourses and practices helps us to understand how those in power "seek to cultivate and sustain an identity as morally valid authority figures" (Tankebe, 2019: 100). This article contributes to the literature on self-legitimation by

\section{Corresponding author:}

Alexandra L Cox, University of Essex, Wivenhoe Park, Colchester, CO4 3SQ, UK.

Email: Alexandra.cox@essex.ac.uk 
exploring how key actors in state criminal justice systems in the United States (US), prosecutors, speak about and justify their power.

Prosecutors have a central and determinative role in the criminal justice system-they decide whether and how to accept police arrests and move them forward into criminal cases. They also decide what crimes people will be charged with. And, because almost all cases are resolved via plea bargaining, they determine the ultimate fate of most defendants. Ironically, despite this tremendous power, prosecutors are typically not required to explain or justify their decisions and, because of plea bargaining, their actions are almost never subject to the processes of discovery and cross-examination that the legal system has enshrined as its mechanisms of accountability. It is vitally important, therefore, to shine light on how prosecutors understand their role and justify their exercise of power.

Our findings draw from in-depth interviews with prosecutors in an office that selfidentifies as "progressive." Our interviews took place at a time when prosecutors across the United States were being criticized in the media and amongst reform advocates for their role in contributing to mass incarceration and racial disparities in the criminal justice system. In this context, our data evidences how a group of frontline prosecutors attempt to differentiate themselves from other criminal justice actors by highlighting the virtuous nature of their work, and from other prosecutors around the country by emphasizing their progressive leaning. Their rhetoric, as we will demonstrate, justifies the very practices that have caused them to come under scrutiny: their considerable discretion, their use of subpoena power, and their monopoly over the plea-bargaining process.

This research about prosecutors' views is part of a larger qualitative study, based on in-depth interviews, about internal organizational legitimacy, self-legitimacy, and emotion management amongst six different groups of frontline criminal justice workers. In this article, we explore how one of these groups, prosecutors, discursively justify their power and authority, and how their rhetoric is aimed at re-gaining or enhancing public legitimacy in the face of a legitimacy crisis. Our findings are based on interviews with 31 prosecutors operating in a politically liberal, Northeastern U.S. city (which we refer to by the pseudonym "Belton"), where some of their ongoing practices, including their reliance on bail, their withholding of discovery materials, and the racially disproportionate outcomes of their prosecutions were being challenged in the media and by the public. ${ }^{1}$

In our interviews, the prosecutors in Belton focused on two dimensions of their authority: their responsibility to act in the interests of the community they represent, and their power to exercise discretion over punishment. By doing so, our interviewees, attempting to respond to claims that they engage in overly punitive, racist strategies, discursively engaged in strategies of legitimation through differentiation. In this effort, they distinguished themselves from three other criminal justice agents, purportedly more deserving of blame: (i) other prosecutors' offices that they deem to be more conservative; (ii) the police, whom they feel they have been unfairly conflated with; and (iii) defense attorneys, whom they describe as bound to their clients' best interests, while prosecutors are committed to "doing justice."

Dovetailing with such rhetoric, the prosecutors engaged in seemingly contradictory claims about justice and the public good. As our interviews have evidenced, although 
prosecutors differentiate themselves from public defenders by emphasizing their superior responsibility to "do justice" and represent the collective interest, they also minimize their role in determining outcomes of the criminal justice system by claiming that their office merely reproduces social and racial inequalities that exist in society at large. They also argue that other legal and political authorities (e.g. judges and state legislatures) have greater authority to effect change. That is, while prosecutors recognize and justify their power by emphasizing their superior and virtuous goal to "do justice," they also shift blame and responsibility for disparate outcomes in the criminal justice system to other actors and "society at large." We argue that such claims add to our understanding of selflegitimation discourses of legal authorities by revealing some of the ways in which "power holders seek to convince themselves that the authority vested in them is morally appropriate" (Akoensi and Tankebe, 2019: 23).

\section{Legitimacy and Self-Legitimation}

Max Weber (1914) pointed to ways in which every system of authority attempts "to establish and to cultivate a belief in its legitimacy." This process of legitimation, he argued, is achieved through the "making of claims" by those in authority, who seek moral validity to their positions (Barker, 2001: 14). Political scientist Rodney Barker argues legitimation is a "self-referential or self-justifying activity characteristic of rulers, pursued with great intensity at the centre of government" (2001: 13). These acts of self-justification play a function in sustaining rules, constituting, and defining, ruling $(2001: 15,30)$.

While Barker's focus is on political actors, Bottoms and Tankebe $(2012,2013)$ argue that legitimation can also be studied amongst criminal justice actors possessing law enforcement authority. In the criminal justice realm, the concept of "self-legitimacy" has been almost exclusively assessed quantitatively, through surveys, and mostly explored amongst police and correctional officers, with an emerging focus on probation officers (Carr and Robinson, 2020; Deering and Feilzer, 2017). Much of the research focuses on relationships between individual power holder's self-perception of legitimacy and recognition by their supervisors, peers, and the public (Bradford and Quinton, 2014; Jonathan-Zamir and Harpaz, 2014; Tankebe, 2010, 2014, 2019; Trinkner et al., 2016). Steve Herbert (2006), who conducted a qualitative analysis of policing in Seattle based on ride-alongs and police-community forums. Herbert argues that the police legitimize themselves by constructing an image of subservience to public demands and needs, and through tactics of "separation" from the public, marking out the ways in which their role is distinctive. More recent work by McEvoy (2019) on "cause" lawyers in conflict and transition zones focused on what he termed the "legitimation work" done by these lawyers. That is, attempts at rationalizing and articulating identities, strategies, relationships and practices, particularly in order to justify practices that were sometimes lawbreaking in contexts of injustice.

A correlate of self-legitimation is that of justification. Sociologists Luc Boltanski and Lawrence Thevenot have developed a theoretical model of social interaction which seeks to understand how actors justify their actions to others (Boltanski and Thévenot, 1999), and how they seek to assert their moral worth when their actions are being challenged or 
perceived as controversial. Their work has been applied in the study of policing and security industries (Côté-Lussier, 2013; Thumala et al., 2011) in order to understand the various logics which police entities use to justify their worth. More recently, this theoretical model was used in an exploration of the "moral cartography" of prosecution (Tuesta, 2021)

\section{Narratives of Legitimation}

Our understanding of how frontline criminal justice workers attempt to self-legitimate can be improved by qualitative assessments of their own narratives. As Barker argues, legitimation involves the work of justifying one's identity as a figure of authority and therefore can be better examined through authorities' discourses and practices. These examinations benefit from "backstage" contexts, where frontline actors tell stories which serve to protect and enhance their status, but also justify their moral authority and worth (Martin and Bradford, 2019). As Reus-Smit (2007) argues, the "social constituency" and the realm of political action in which legitimacy claims take place shed important light on the legitimation process. In this article we contribute to investigations of legitimation strategies by examining prosecutors' discourses. Our findings add both to the knowledge of self-legitimacy strategies by expanding the area of study to prosecutors, as well as to the understanding of prosecutors' views of their own power and legitimacy.

\section{Prosecutors: Powerful Agents of the State}

Prosecutors are agents of law enforcement also charged with police accountability. As state agents, they have broad charging authority and discretion, they have the power to subpoena witnesses, possess a broad range of discovery materials, recommend bail conditions, establish the minimum sentence in a plea, and dismiss cases. In an early article about the role of the prosecutor, US Attorney Robert Jackson argued that the prosecutor "has more control over life, liberty, and reputation than any other person in America. His discretion is tremendous" (1940: 3). Legal scholar Angela Davis (2005) argues that prosecutors are the "most powerful" figures in the American justice system, particularly through their power to charge and plea-bargain, an idea that has been echoed by others (Bazelon, 2019; Miller, 2004; Pfaff, 2017; Sklansky, 2018).

Prosecutors also have unique interactions with citizens and the public. Unlike law enforcement agents, they do not wear a uniform and do not always serve their law enforcement role in public. The courtroom, judge's chambers, and prosecutors' offices where plea agreements are negotiated are far less available to public scrutiny than a street corner, private residence, or other location where the typical arrest occurs. Moreover, as unpacked in Malcolm Feeley's classic work (1979), prosecutors' plea offers are influenced by a range of factors that determine a "case's worth"-that is, pieces of information used during interactions between defense attorneys and prosecutors to frame characters and situations.

Scholars have previously examined the ways that prosecutors seek to justify their decision-making practices, focusing primarily on issues of prosecutorial discretion and charging decisions. They have focused, for example, on the role of victim characteristics 
in prosecutorial decision-making (Frohmann, 1997; Spohn et al., 1987). Frohmann (1991), for example, found that prosecutors focus on convictability, developing typologies of credible victims in sexual assault and rape cases. Spohn et al. (2001) extended this work, finding a wider range of "focal concerns" that prosecutors draw from in making their charging decisions in sexual assault cases. Wright et al. (forthcoming) created an experiment that documented wild heterogeneity in prosecutors' charging practices and the lack of meaningful supervision or guidelines that line attorneys receive. More recent work has examined the role that efficiency plays in prosecutorial decision-making (Spohn, 2014), but overlooked the broader socio-political and institutional landscapes in which prosecutors make, and ultimately justify, their decisions (Tuesta, 2021).

It is important to look at a few dimensions of prosecutorial discretion when studying authority, legitimacy and democratic accountability. One, prosecutors are democratically accountable; most jurisdictions in America elect their chief prosecutors. ${ }^{2}$ Two, prosecutors' power to charge people with crimes and offer pleas gives them a unique influence over individual freedom. As Pfaff (2017) argued, plea bargains, as opposed to legislative actions, play a role in setting the minimum tariff for a sentence. Prosecutorial discretion impacts citizens' experiences of the criminal justice system's democratic dimensions as well as its punitiveness. It is also true that prosecutors rarely receive criticism or feedback for their work from the people who appear before them in court; they are, however, particularly chief prosecutors, exposed to democratic accountability by the public more broadly.

There is some research on what drives citizen perceptions of prosecutors, suggesting a relationship between those perceptions and broader satisfaction with the justice system. Most of this research corroborates the idea of procedural justice, advanced by Tom Tyler and colleagues (Tyler, 1990; Tyler and Jackson, 2013). According to procedural justice theory, positive assessments of encounters between the public and legal authorities increase trust and perceptions of these authorities' legitimacy, which in turn fosternormative, voluntary rule-compliance. The extant literature, however, suggests but has not yet conclusively demonstrated the role played by prosecutors' procedurally just practices in shaping the legitimacy of their offices or the criminal justice system more generally. More important for our discussion, it also leaves open the question about how prosecutors perceive their own legitimacy, particularly in the context of critiques to their power as a driver of mass incarceration and racial disparities in the criminal justice system.

\section{Methodology}

The larger study on which this article is based was aimed at understanding the legitimation strategies of criminal justice frontline workers, their perceptions of internal (organizational) legitimacy, their emotional management strategies, and their broader perceptions of systemic legitimacy. The study relied on in-depth semi-structured interviews with 170 frontline criminal justice workers in a large Northeastern city. Participants included prosecutors, criminal defense attorneys, pretrial associates who interview individuals accused of crimes before arraignment, judges, correction officers, and probation officers. The study sought to capture the breadth and depth of micro-level 
processes and their relationship to macro-level structures. For this article, we rely exclusively on interviews with prosecutors, working in different bureaus of the same office.

The interviews with prosecutors took place over the course of three months (in 20172018) and were conducted outside of prosecutors' workplaces to allow them more freedom to make somewhat objective assessments of their work (Gagnon and Richards, 2008, McDowell, 1998). Informed by the extant literature on self-legitimacy and emotional labor, the semi-structured interview schedule was organized around several core themes: worker identities and attachment to their agencies, worker perceptions of self-legitimacy and authority, emotion management strategies in their interactions with the public, and perceptions of the legitimacy and fairness of the system they work in.

\section{Sampling Strategy}

The aim of the larger study was to purposively select a sample of 30 individuals from each category of criminal justice worker, seeking diversity in the sample in order to explore issues related to resource distribution and access, policy reform, and systemic fairness. Our sample of 31 assistant district attorneys (ADAs) was selected from a pool of 123 volunteers, considering their diversity of age, race, gender, as well as position and tenure.

The average age of employees in the prosecutor's office of Belton is 39.5, and the average tenure is 9.9 years. Our sample of 31 prosecutors is slightly older and more experienced than the average prosecutor in Belton. Our interviewees are overwhelmingly aged 30-49 (77\%), with 10 to 20 years on the job. Gender-wise, our sample was much like the population of prosecutors in Belton, with women representing close to $55 \%$ of the sample. The racial distribution of our sample closely approximates the racial distribution of the Belton office staff except for the number of Asians. In our sample, $58 \%$ of prosecutors identified as White, 16\% Black, 19\% Latino/a, and 3\% Asian. The office staff is $58 \%$ White, $17 \%$ Black, $16 \%$ Latino/a, and 9\% Asian.

Belton is a jurisdiction with a high volume of criminal cases that go through the courts every year-in excess of 10,000 pending cases at any time, and over 70,000 cases are yearly arraigned. Much like other jurisdictions across the country, over $75 \%$ of cases that go through arraignments are misdemeanors, many of which are disposed of at that stage, and less than one percent are felonies. On average, ADAs in Belton are required to handle over 250 cases at any given time. Despite current consensus on the negative consequences of mass imprisonment, in Belton, the vast majority of people convicted of felonies which resulted in a sentence are handed a prison sentence (Table 1). ${ }^{3}$

We engaged in a theoretically driven, inductive approach to analyzing the data. First, we drew from a strategy advanced by Deterding and Waters (2018), in which they argue for "flexible coding," indexing our data with codes that derived from our interview questions and theoretical concerns. We then created sub-codes within those index codes which reflected our more fine-grained concerns. Based on a coding manual, two researchers trained in the relevant literature used MAXQDA software to code transcripts. Research team leads checked the coding process to ensure intercoder reliability. 
Table I. Sample demographic characteristics.

\begin{tabular}{lcc}
\hline Tenure in years & Frequency & Percentage \\
$10-20$ & 11 & 35.48 \\
$5-10$ years & 10 & 32.26 \\
$1-5$ & 6 & 19.35 \\
$20+$ & 4 & 12.90 \\
Total & 31 & 100.00 \\
Gender & Frequency & Percentage \\
Female & 17 & 54.84 \\
Male & 14 & 45.16 \\
Total & 31 & 100.00 \\
Age group & Frequency & Percentage \\
$30-49$ & 24 & 77.42 \\
$50-64$ & 5 & 16.13 \\
I8-29 & 2 & 6.45 \\
Total & 31 & 100.00 \\
Race & Frequency & Percentage \\
White & 18 & 58.06 \\
Black or African American & 5 & 16.13 \\
Latino/a or Hispanic & 4 & 12.90 \\
Latino/a or Hispanic, White & 2 & 6.45 \\
Asian & 1 & 3.23 \\
Other: Please Describe & 1 & 3.23 \\
Total & 31 & 100.00 \\
\hline
\end{tabular}

Our analytical strategy focused on identifying themes, core relationships and patterns emerging from the data. Building from the coding process, we engaged in a content analysis of prosecutor's legitimation strategies, identifying core themes within those strategies. We also drew upon critical discourse analysis approaches (Foucault, 1980; Howarth, 2000) to study the "legitimacy claims" (Reus-Schmidt, 2007: 160) of prosecutors as a way of understanding their production and reproduction of authority. Discourses and power structures are mutually constitutive (Howarth, 2000), and prosecutors' ways of thinking and acting within the juridical field in which they operate has implications for studying prosecutorial power (Bourdieu, 1987).

\section{Findings}

\section{Legitimation Through Differentiation}

Critical discourse analysis uncovers how identity discourse often leans on "positional superiority," that is, the focus on negative features of the other and the positive attributes of the self, while underestimating positive characteristics of the other and the negative qualities of the self (van Dijk, 1995). "Positional superiority" was a notable discursive strategy amongst our interviewees in Belton. This relates to social psychologist Tajfel's (1978) notion of differentiation as a form of exaggeration, which works to bolster and protect the identity of the prosecutor group. By focusing on their positive 
attributes and differentiating themselves from prosecutors elsewhere and other criminal justice actors, Belton prosecutors justified their position and discretion in the face of threats and suspicion of their role.

Throughout their interviews, Belton prosecutors focused on the "honorable" exercise of the discretionary power that the system entrusts their office with, and their commitment to "doing the right thing." Focusing on their symbolic capital, which Bourdieu (1984: 291) has described as "reputation for competence and reliance on an image of respectability and honorability," our interviewees repeatedly invoked their commitment to "doing justice." "Doing justice" is a term that has been legally enshrined as an obligation of prosecutors in the US Supreme Court Sutherland opinion, but has also been recognized as "protean as well as vague" in the context of prosecutorial practice (1999: 608).

Multiple prosecutors used the expressions "do justice" and "do the right thing" with great frequency over the course of the interviews, suggesting the ways that these forms of positional superiority are embedded in their organizational vocabularies. The prosecutors' invocation of language about "doing justice" not only invokes their symbolic capital but also points to a justification of their actions - and worth - that appeals to a collective, civic interest in public safety (Boltanski and Thévenot, 1999).

While focusing on their honorable albeit vague mandate to "do justice," prosecutors justified and attempted to legitimize their superior power vis-à-vis the morally "inferior," narrower interests of other actors; i.e. (i) other "non-progressive" prosecutors, who are focused on convictions; (ii) the police, who are concerned about arrests, (iii) and defenders, who are subservient to their individual client's best interest ${ }^{4}$ Below, we explore how Belton prosecutors expressed these ideas of legitimation through differentiation.

Belton: A Progressive Office. One strategy of positional superiority that Belton prosecutors engaged in was to label themselves and their office as "progressive" in relationship to other offices. This was bolstered by their positioning in an office where the lead prosecutor himself identified as "progressive," invested in reforms targeted at reducing the prosecution of low-level crimes, claimed to rely on "data-driven" prosecution, and sought to include training on implicit bias and the collateral consequences of incarceration.

Promoting this representation, a number of interviewees described their office as distinct from other conservatively-minded offices around the country. Patricia, a Latina who worked in the office for 11 years, for example, emphasized that "[Belton] is not Alabama," expressing frustration about the media narrative on corruption and miscarriages of justice by police and prosecutors, but pointing to the greater frequency of these patterns in Southern, ostensibly more racist contexts.

Some of the prosecutors referred to the Belton staff as educated and more politically liberal people, unlike other offices. They advanced claims about their identities as informing decisions that were fairer than elsewhere. Renee, a Black female prosecutor in her 16 th year on the job, for example, noted that "We are better. We do a better job. We have a lot more resources. And so, I think, sometimes we might get grouped intomore lumped into some of the more extreme cases you might hear around the country, or even the state, like [a rural part of the state], like town judges and things like that." Similarly, Tom, a white male prosecutor who grew up in Belton and worked at the 
office for 12 years, felt that it was important to defend his office as a "progressive" and distinct one:

...sometimes there are assumptions that prosecutors are just out to get wins, or don't care about the rights of the defendants, or aren't cognizant of or are too cavalier about the harm that's being inflicted on people who are incarcerated... an easy assumption to the extent that anyone ever talked about prosecutors that they didn't really care that much about who they were prosecuting, or the consequences of those prosecutions, and that the criminal justice system is racially discriminatory, and that there's a thread of injustice, if not a river of injustice, that undergirded the entire system. You have to evaluate every criminal justice agency and community on its own terms and see. That may very well be true for some, but I really don't think that's true in [Belton] in the way that sometimes is a common stereotype.

For Tom, it was important to express his identity as a progressive person and a Belton prosecutor, noting that his office's practices do not match the common "stereotype" about prosecutors being excessively focused on convictions. Interestingly, Belton prosecutors did not seek to dismantle the perceived stereotype, but merely to differentiate themselves from it. As discussed by Chilton (2003) in his analyses of political discourse, legitimation, and by consequence, delegitimation, can manifest themselves in attempts to present the other in a negative lens, and the self, in contrast, as worthy of praise.

Building on the need to stake out a difference between Belton and other jurisdictions, a number of prosecutors focused on their putative commitment to exercising restraint in incarceration, particularly for non-violent crimes. After distinguishing her work from that in other more rural areas, Renee said that "It's really only violent crime that you're-that we're gonna be recommending jail right off the bat. That's it." Differentiation from other locations which prosecutors deemed to be more punitive or focused on incarceration was an example of their repertoire of legitimation and positional superiority - their jurisdiction was one they saw as more enlightened than others.

It is noteworthy, however, that not all prosecutors endorsed the view that Belton's status is unique. Andrew, a white male with five years in the office suggested that Belton's sense of its own progressiveness may have been inflated:

... I can't say now what is some small, [rural] office doing? What do the folks there believe? I really have no idea. Clearly, there has been a history in the US of prosecutors' offices not being particularly conscious of systemic inequality or problems in the criminal justice system. The Belton DA's office isn't unique in having become conscious of this.

This slightly divergent view reveals an understanding that although not unique in their status, Belton prosecutors still saw themselves in a positive, self-praising manner.

Differentiation from the Police. Another way in which prosecutors sought to legitimize their professional moral worth was by distinguishing themselves from the "tainted trade" (Thumala et al., 2011) of policing. As indicated above, the crisis of prosecution 
dovetailed with a crisis of policing, when certain practices were exposed as illegitimate, racially discriminatory, aggressive, and often lethal.

Several prosecutors in Belton felt the need to distinguish their work from police work, emphasizing their "superior role" to protect collective interests by promoting public safety and enforcing punishment.

A number of interviewees felt that the conflation of police and prosecution work was dangerous and sought to deconstruct the public misperception that the two institutions are aligned or even indistinguishable. Ben, a white male with 11 years in the office, argued that prominent cases of police brutality going as far back as the 1990s "inform peoples' perceptions of the office," thus implicitly linking the prosecutors' image to perceptions of police. Prosecutors felt that this conflation of roles may contribute to legal cynicism. For example, James, a white male deputy bureau chief with 14 years in the office, said:

...I think the trend that I sort of pick up on is that people are more cynical of law enforcement in general - more police than prosecutors, but also prosecutors, less trusting of police, prosecutors, and the criminal justice system than they were when I started in the district attorney's office 14-plus years ago...So, for example, a lot of times people who I come into contact with professionally are inclined to lump me together with at a minimum the police, but sometimes other actors like judges, even court officers, even defense attorneys sometimes. So, sometimes the way that people are treated by some of those other actors will influence how they feel about me.

Ben's assumption is that the individuals he comes into contact with view him symbolically as a member of a larger system working against their interests.

Other interviewees focused on how perceptions of racially biased policing frequently spill over to prosecutors' offices. According to Shelly, a Black female prosecutor with 28 years in the office:

They think we're the devil. I shouldn't say that. I don't think all people think that. I do think that there are some people who just believe that because we're so associated with [the police department] that we get wrapped into all of that about law enforcement and who we are and what we are and I think that it's unfortunate because people then just don't see us as being just and fair and just see us as going after people.

Shelly points to police racism shaping negative public perceptions of the work of prosecutors in their dealings with witnesses and defendants. In the eyes of prosecutors, this fallacious conflation of prosecutors and police, a distinct agency with its own mission, values and practices, serves to unfairly delegitimize their professional category.

Interestingly, however, shortly before the interviews took place, news with data about the role of race in prosecution were released, indicating potential racial bias involved in prosecutorial decision making in Belton. Several interviewees acknowledged the existence of this data but sought to diminish its significance. ${ }^{5}$

Other prosecutors expressed that the contemporary media contributes to the negative image of both police and prosecution. Alina, a Latina prosecutor in her $30 \mathrm{~s}$, with five years on the job, said "I think the attitude is very anti-police, anti-prosecution. I don't 
think that there are many articles, if we did a search right now, where you would look that have a very favorable or positive attitude towards prosecution. ... I've never read an article where it's, like, wow, look at these fantastic prosecutors doing this fantastic work." Alina equated the negative public perception of prosecutors and police with the media portrayal of them.

Some of the more self-identified "progressive" prosecutors expressed a level of defensiveness about the taint of their role, indicating frustration with the notion that prosecution is not viewed as a public good. Jon, a young Black male prosecutor in his second year on the job, implicitly recognized the public discontent with the police through his comment about public perceptions of prosecutors: "They view us as an arm of the police, which is not true. We work with the police. We work with them closely. But we're not here to be the police's friend necessarily. ...I think a lot of people do not think of prosecution as a public good, as a public interest They view it as law enforcement or something." Jon's comments evidence knowledge of the mutual dependence of police and prosecutors (Harris, 2012), but also difficulty in conveying how disparate the entities are. Ben, a white male prosecutor with 11 years on the job, suggested that prosecutors who aren't necessarily pro-law enforcement get lumped together with those who potentially are:

And there's been - a conflation, I think, of the police department and the prosecutors - and there are plenty of prosecutors that do not agree with a lot of police conduct and being made to kind of -be the ambassador for the police department. I'm of a very left-wing group of friends outside of the office and constantly feeling like the ambassador to them is interesting.

Others, like Ben, even acknowledged that there may be some validity to the poor perception of the police, and by extension, law enforcement more generally, but pointed to the conflation of law enforcement and police as a dangerous one. Andrew, a white male prosecutor with five years on the job, noted:

There's a conflating of the DA's office and the police, which I mean I would say is abstractly incorrect, but I understand why people feel that way. I understand that we are perceived from the outside as being not necessarily the same thing, but joined at the hip. That's not an unreasonable view of somebody outside the criminal justice system who's been on the other side of it.

Other prosecutors pointed to the police as yet another figure in the criminal justice landscape who they had to interact with, and sometimes be in an adversarial role with. Shelly, a Black female prosecutor who, perhaps emboldened by her length of service (28 years on the job), even said that if there was one reform she could make to the system, it would be to "Blow up [the police department]." She continued:

I don't mean that figuratively - literally. I just still think that a lot of so much stems from them, because they sometimes are the actors that start processes, and as long as their systems are flawed - be it racial profiling or how their members are interacting - there's 
gonna be problems in the system, and if we can't have faith in the people who really are at the core of the system...

Prosecutors' attempts to differentiate themselves from the police are complex in light of their status as both agents of law enforcement and adjudicators of the law-what Sklansky characterized as "pass[ing] back and forth between these two worlds" (2016: 503). Thus, in the context of a legitimacy crisis about police nationally, their efforts to differentiate themselves from the police are fraught with tension. That is because prosecutors must work with the police, both by presenting and defending their work in court and by overseeing them, and ensuring that they comply with the law (Sklansky, 2016: 503).

Differentiation from Defense Attorneys. Our interviewees also distinguished themselves from defense attorneys, whom they described as intent on securing clients' interests, while prosecutors see themselves as representatives of the collective interest. This differentiation is clear in their descriptions of defense attorneys as determined to get an acquittal or "the best deal that they possibly can for their client no matter what. They don't care how bad this person is or what the crime is, or whatever. That's their job" according to Lisa, a white prosecutor with five years on the job. Similarly, Barbara sought to distinguish her approach to professional practice from that of defense attorneys:

...you have defense attorneys who go up there, and they are not - they're not concerned about justice, and that's fine. That's their job. Their job is to get the best outcome for their client, whatever the cost is.... they can't be concerned with society's greater interest They can't be concerned about the victim. They're there for a specific job, and it's an important job, and so that's what they're concerned with.

Tom also positioned himself on the side of "right" with respect to defense attorneys, noting that "It's a little bold but I think it's fundamentally true which is not to knock defense attorneys. They're doing an important job too and making sure that the rights of defendants are upheld. But when someone rapes someone or shoots them and then shoots an innocent bystander, you're on the side of right and you're trying to do the right thing, whatever that is." This distinction is more of a rhetorical one than that which falls within the scope of professional practice and the law, which enumerates the defense role as ensuring that their clients' constitutional and legal rights are protected. Prosecutors' strategies to distinguish themselves from defense attorneys could also be an effort to assert power in a legal hierarchy of relations in what Bourdieu (1984) has described as the "juridical field," endowing them with "symbolic capital" (Bourdieu, 1977), as morally superior and upright.

One controversy at the time of the research was whether the prosecution should move to an "open file" model of discovery, which some groups of defense attorneys were pushing for. In a "closed file" discovery system prosecutors are allowed to withhold discovery information until the date of trial (Turner and Redlich, 2016). This contributes to prosecutor's power to make a "one-sided presentation of the facts" (Jackson, 1940: 3) in their cases. Thus, rather than being a clear-cut source of authority related to their power 
over the freedom of the accused, it revealed their moral authority to pursue a conviction, and what Bourdieu might term the "structurally organized competition" (1987: 818) between defense attorneys and prosecutors. This competition reflects a division of labor between prosecutors and defense attorneys which involves a set of power relations between the two groups. These power relations also often involve a power imbalance, reflected in the prosecutor's ability to withhold evidence from the defense. This ability to withhold evidence is a form of discretion because it reveals their power to deploy information strategically, in service of their desired outcome for the case, but also contributes to a form of competition that shapes access to legal resources for defense attorneys, but also ultimately members of the public.

Lee, an Asian attorney with ten years in the office, sought to justify her decision to withhold discovery materials in some cases by invoking prosecutors' virtuous forms of discretion and trustworthiness: "This is why I think it's very challenging... in a lot of ways, prosecutors have to hold the information close. So, we want to-We are bound by our job not to give out too much information, and to protect witnesses, and to protect people's privacy. At the same time, we're supposed to be projecting a sense of, "Well, we're doing the right thing." The language of doing the "right thing" was used by Lee here to position prosecutors as morally superior guarantors of public safety. These assertions of virtue and moral worth-and an appeal to the role of prosecutors in upholding the collective interest in public safety (Boltanski and Thévenot, 1999) allow the prosecutors to justify their decisions which arguably disadvantages the defendants.

Other prosecutors spoke about their decisions to disclose discovery materials as a choice about fairness and one which implied that their behavior was decent. Ian, a white prosecutor with 14 years on the job, said 'I'm pretty upfront with defense counsels about the evidence in a case. I turn the evidence over as soon as I'm allowed to, basically. Once it's an appropriate time to do that, I'm happy to do it early on." Even in speaking about his general disposition of being "upfront," Ian implicitly recognized his authority here to withhold evidence, and his powerful possession of discretion, justifying the broader source of authority which allows him to reveal such evidence.

A number of interviewees recognized the public perception that prosecutors are overwhelmingly focused on punishment, not on promoting safety and well-being. Lisa spoke about this perception in response to a question about what distinguished her profession from others in public service:

You tell people you're in public service, and they're like, "Oh, that's so wonderful." Like, if you're a social worker. Unless you're that part [of a child protective services agency] .... that's taking people's kids away, and even then, you can be like, "Oh, I'm protecting kids," but very few people perceive being a prosecutor as having anything to do with helping victims, or they hear you're a prosecutor and they're not thinking about my victim who's an illegal immigrant, sex traffic, getting beat up by people. They're thinking, 'Oh, you're just putting people in jail for no reason.'

Several of the prosecutors were defensive about what they think is the public perception that their work is focused on incarceration. This defensiveness is particularly noteworthy 
in a context where the overuse of incarceration has been widely criticized in the media and public discourse. Some prosecutors pointed to the criminal defense bar as perpetuator of the view that they are only intent on sending people to prison. Samantha, a white prosecutor with 10 years in the office, said that defenders propagate the view that "prosecutors are pieces of shit who just don't want-who all they want to do is put people in jail and nothing else matters."

The prosecutors in Belton recognized that they face legitimacy challenges as a professional group and as part of the criminal justice system. Thus, they also sought to differentiate themselves from other criminal justice actors, namely other, non-progressive prosecutors, police officers and defense attorneys.

In engaging in this strategy of legitimation through differentiation, prosecutors sought to assert their moral, intellectual, and social superiority in the juridical field, emphasizing their alleged ability to exercise parsimonious punishment, to hold institutions like the police accountable for their wrongdoings, and for their commitment to "doing justice." We argue that this strategy allows room for prosecutors to justify several practices that have been identified as leading to systemic unfairness: the withholding of discovery evidence, their own potential engagement in charging practices which had a disproportionately negative impact on people of color, and their focus in securing convictions, albeit for violent crimes.

\section{Displacing Blame}

The legitimacy crisis facing prosecution has been fueled by a broader challenge to systemic injustices - the deep racial disparities in sentencing and punishment, the convergences of race, class and gender in shaping people's outcomes in the system, and the lengthy prison terms and overincarceration of broad swathes of the American population. Several of the prosecutors in Belton recognized these systemic injustices and challenges facing the criminally accused. Yet, and contradictorily, while justifying their power based on their professional commitment to "doing justice," they simultaneously sought to minimize their power and authority in effecting change in people's lives, placing that responsibility onto other systems out of or beyond their control. Thus, they also engaged in what we argue are strategies of legitimation through the displacement of blame. We argue that displacement of blame involves attempts to justify their power and authority, and thus actually entrench that authority.

\section{Minimizing Power}

As discussed above, the power and authority of prosecutors have been widely recognized in the research literature, as well as the popular press. Prosecutors in our sample however, often expressed ambivalence about this power, at times overtly recognizing it (i.e. Jocelyn argued that "we have the power of God, right, the power to take away someone's freedom") while at times engaging in more equivocal reasoning. For example, some suggested that their discretionary power to charge and offer pleas is limited by police practices and incompetence, supervisory control, and judicial power. Jon, for example, argued that their discretion is hindered by "red tape and bureaucracy." Similarly, Alice, a white 
prosecutor with 10 years in the office, argued that "there are guidelines and rules and reasons why things are done, and to deviate from those, you have to get a lot of approvals," suggesting that the public doesn't recognize how limited their power actually is. Valerie, a white female prosecutor with 14 years in the office also minimized her power in the face of the public perception of it: "I think a lot of people fear that we have more power - that we might have the power to put them in jail or something. Something like that can kind of happen, but it's very rare and it's not up to us, at the end of the day."

Several prosecutors suggested, in other words, that their ability to make decisions was hampered by legal systems out of their control. Interviewees' recognition of the limits on their authority is both a discursive attempt at minimizing it, but also reveals an important dialogic aspects of their legitimacy - these prosecutors argue that they can only enact their discretion because or when they are given permission to by other agents of authority-those they believe are more powerful than them (see Martin and Bradford, 2019: 10). As Martin and Bradford argue in the context of policing, "[1]egitimation is therefore a process not only contingent on how police claims are received by audiences but also on what is, and is not, possible within relevant institutional and socio-cultural frameworks" (2019: 11).

These attempts to discursively minimize their authority suggests that prosecutors were not only aware of the expansiveness of it, but also equally conscious of the need to minimize their responsibility for and power over the damages associated with the criminal justice system. As indicated above, the prosecutors were well aware of critiques of the system, both from within the system (e.g. by defense attorneys), and by the public.

\section{Displacing Responsibility}

Almost all of our interviewees acknowledged the crisis of legitimacy of prosecution with respect to racism and systemic injustice, frequently using the term "mass incarceration," which suggested at least a nominal nod to the politics of punishment. The prosecutors' recognition and critique of some of the core issues highlighted in debates about mass incarceration - racial disparities, impacts of incarceration on families and communities, "implicit bias" in policing and prosecution, and the problems with cash bail-were acknowledged, yet presented as an outcome of other agents' actions, systemic unfairness, larger socioeconomic disparities, mandatory sentencing and other macro-level explanations. For example, a number of the prosecutors spoke about their concerns about the police arrest of individuals for low-level offenses, and the injustices that potentially come along once these individuals are caught up in the system. For example, Jon, the young Black prosecutor who is relatively new on the job and covers a number of lowlevel offenses, argued:

I have a hard time prosecuting people for low-level crimes in which I believe that the prosecution of the people does more harm than good. And when I'm dealing with an arrest, when a person comes in and I read an arrest report and the arrest report says, "This person has been arrested for an A misdemeanor, say reckless endangerment because they were dancing on [public transportation]." I'm like, "Are you kidding me?" First of all, 
that's not the crime, right? The best you've got is disorderly conduct in my view. Playing loud music and being annoying. But to say that this person put other people at substantial risk of serious physical injury or death is you reaching.

Jon blamed the police for "unnecessary arrests" of those who commit minor offenses, especially the homeless, and spoke about the pressures they face from police officers to prosecute low level crimes, such as disorderly conduct. He also spoke about the unfairness of the bail system, but again pointed to the Belton office as an exception to the rule in punitive bail-setting practices.

When asked about actors with the ability to effect change, most prosecutors emphasized the greater power of judges and legislators, minimizing their ability to promote change beyond the scope of individual cases. Barbara, for instance, a young Latina with less than five years on the job, spoke about the different pace of change that legislators and prosecutors can potentially effect.

I also think the legislature, obviously, has a way bigger ability to change the way this happens, for example, with a drug legislation, right? If tomorrow, the legislature decides to legalize marijuana, boom, no more of any marijuana cases at all, which, right now, the office sort of tries to piece together their own ways of combatting the legislature that is so slow to change, that you just find your own way of trying to do justice without the legislature actually changing the statute, which would change things a lot faster.

This argument overlooks prosecutors' powerful clout, as identified by authors like Lisa Miller (2008) and Michael Campbell (2011). Both scholars have shown how prosecutors play a key role in shaping criminal law and criminal justice policy through their influence in the political arena. They have demonstrated how, in different states, prosecutors (individually or through their associations and legislative committees) exercise political influence by lobbying, communicating with legislators and giving testimonies in public hearings. In Belton, individual prosecutors are represented by a statewide lobbying organization.

Other discursive strategies involved acknowledgement of unfairness in the criminal justice system, but attribution of that to society at large, minimizing the role of prosecutors in determining injustices. Ben, for instance, acknowledged the existence of unfairness in the criminal justice system, but said its roots were in other ancillary social systems: "I don't think the system as constructed is fair, but I think there's a lot of people within it, trying to apply it - trying to apply a fundamentally unfair system in a fair manner. And I go back to the problem with a criminal justice system as a system is that it's not its own system. It exists at the end of the failure of every other system in the city." Ben went on to describe the hypothetical scenario of a teenager charged with a violent crime, suggesting that his own decision to applying the rule of law to that person's case was a necessary consequence, but unrelated to what led the teenager to participate in the violence in the first place:

If parents or schools or churches or community groups had done something earlier in the kid's process they may not have ended up doing the violent thing they did at 17 or 18 
years old. And then is the system fair to that 17 or 18 year old? Can you say it's fair because we followed all the rules of evidence and because all the discovery was provided in a timely fashion?

Ben differentiates between what's procedurally fair (in terms of adherence to the laws, rules and procedures governing criminal prosecutions) and what is morally fair (considering the set of circumstances that leads an adolescent to commit a violent act). Similarly, other prosecutors pointed to what they argued was their fair and just practice in a case, and how that is importantly distinct from issues of systemic unfairness.

Others acknowledged systemic unfairness, but then went on to speak about their role in combatting crime and ensuring public safety. Jerry, for example, defensively argued that the critique of mass incarceration didn't allow people to see the "actual facts of a case":

I think it's easier for someone who's not in it [the criminal justice system] and making the decisions to say that there's problems with mass incarceration and this and that - which I think is totally true - and then when you're face-to-face with the actual facts of the case and with victims who are being abused and this and that, to come to the right determination on what things to do with the - .Well, while the office has a lot of resources and a lot of power, there are limits and there's not as many resources on a larger, macro, kind of holistic level for criminal justice reform that our office can implement.

The prosecutors' strategies of legitimation through displacement of responsibility and blame revealed the power that they have to shape the meaning of "fairness" in the context of their cases. For them, a fair or neutral approach to cases is one that was not only "race blind" but also neutral with respect to the facts of a case. Their emphasis on the cases in front of them is one that reflects a complex split: this split involves an acknowledgement of structural racism and injustice, but also an assertion of immunity from such forces in their own decision-making. In other words, the facts of the case itself are primary to their work. Yet, in making the assertion that systemic injustices are and continue to be located elsewhere, prosecutors justify the relatively broad powers they possess to set bail, to engage in plea bargaining and set a minimum prison sentence, and ultimately, to shape an individual's freedom.

\section{Conclusion}

Our observations took place in the context of a legitimacy crisis about the institution of prosecution, when a number of commentators have argued that prosecutorial power has played a crucial role in driving mass incarceration, and contributed to the excesses and distortions of the American criminal justice system (Bazelon, 2019; Simon, 2007; Sklansky, 2016). We argue that the research that has already been done in the area of selflegitimacy only focuses on how rates of self-legitimacy (measured as a quantum of selflegitimacy) relate to self-confidence and perceived audience legitimacy (Bradford and Quinton, 2014; Jonathan-Zamir and Harpaz, 2014; Tankebe, 2010; Tankebe, 2014; Tankebe, 2019; Trinkner et al., 2016); but these studies do not give us much information 
about the shape and structure of power from powerholders' perspectives. We thus explore prosecutors' self-legitimation strategies, contributing to knowledge in this area.

We argue that the recent movement in the United States amongst prosecutors to develop seemingly more "progressive" practices—embracing leniency, addressing racial disparities, and criticizing mass incarceration-provides a unique window through which self-legitimacy strategies can be studied, as this effort signals a recognition amongst prosecutors themselves that their role has faced challenges to its legitimacy. We found that prosecutors see their role as morally virtuous despite social and racial inequalities which they claim to bear little to no responsibility for perpetuating. These positions may also reflect the limitations of the law as a vehicle to address issues of systemic injustice.

The broad power of prosecutors to punish in the democratic state makes them a worthwhile object of study in the context of legitimacy. Not only are chief prosecutors democratically elected and accountable to the broader citizenry, frontline prosecutors interact regularly with a wide range of court actors, individuals accused of crimes, victims, and witnesses. Thus, the way in which they speak about their role reveals a great deal about the contours of their power.

By examining prosecutors' discursive strategies, we made two core findings: one, recognizing the legitimacy challenge facing prosecutors more generally, Belton prosecutors seek to differentiate themselves from other criminal justice actors whom they deem responsible for mass incarceration. In doing so, they seek to assert their moral, intellectual and social superiority in that they are seen to engage in practices which are less "backwards" and punitive than other actors. Two, recognizing the systemic injustices and challenges facing the criminally accused, the prosecutors displace their power and authority in effecting change in these individuals' lives to other systems and institutions.

These discursive strategies of legitimation through differentiation and legitimation through displacement of blame that our interviewees engaged in revealed their efforts at upholding rather than limiting their power and authority. Through differentiating themselves from the police, prosecutors assert their capacities to exercise authority over police decision making, to hold them accountable, and to make full and final decisions to pursue convictions. Yet, the paradox of the discourse of differentiation from the police-in which the prosecutors seek to distance themselves from that "tainted trade" (Thumala et al., 2011) — is that they simultaneously seek to legitimize their own broad authority to enforce the law. In doing so, they justify practices which may be outwardly perceived and experienced as harmful-the withholding of discovery, the vigorous pursuit of lengthy sentences for people charged with violent offenses, and the racially disproportionate outcomes of their charging decisions-by appealing to civic virtues of the collective interest in public safety.

Bottoms and Tankebe (2013) point to the dialogue between criminal justice agents and citizens. Our research suggests another important dialogic dimension of legitimationthe relationship between prosecutors and other legal actors in the juridical field (Bourdieu, 1984). Sklansky argues that the power of prosecutors is their "ability to cause outcomes through influence" (2016: 483). He then suggests "some of the prosecutors' influence stems less from their ability to make threats or promises than from their air of authority and their ongoing relationships with judges, probation officers, law 
enforcement agents, and legislators" (2016: 484). The prosecutors in Belton sought to legitimize their position in that relational maze, and their dependency on others to secure cooperation within it, through their assertions of moral authority and "symbolic capital" (Bourdieu, 1984).

As some of the leading theorists of legitimacy have argued, "power-holders must derive their authority from and act within the shared beliefs and values of a given society" (Beetham, 1991; Bottoms and Tankebe, 2012; Coicaud, 2002: 141). The prosecutors in Belton recognized that those shared beliefs had become fractured-that a number of members of the public had criticized the institution of prosecution for failing to uphold the core values and beliefs of fairness and mercy. A number of the prosecutors in Belton recognized the critiques of their institution, particularly in terms of the effects of the prosecution of low-level offenses, but through their discourses of blame displacement, they then sought to distance themselves from responsibility for such failings.

Herbert (2006: 483) argues that "state officials often construct their actions as consistent with certain universal goals, such as equality, freedom and justice" in order to legitimate themselves. In Herbert's (2006) research about police officers in Seattle, he found that police would draw distinctions between themselves and members of the public through strategies of separation, asserting their autonomy and authority. Bottoms and Tankebe have argued that power holders "have a need to view themselves as serving a purpose that transcends simply remaining in power," and that criminal justice power holders may be particularly committed to the view that they are maintaining a "just social order" (2013: 71). In Belton, we found that prosecutors asserted their moral authority as progressive prosecutors, committed to fairness, justice, and the recognition of systemic bias, in order to justify their use of a broad range of powers.

In order to legitimize their role, the prosecutors engaged in a two-tiered strategy, one that sought to convey recognition of the negative impacts of the system, thus implicitly addressing the audience of critics in their social base, but also one that asserted their material authority and power but spoke to their political and moral source of authority. Their discourses of differentiation were strategies aimed at pointing to their exceptionalism, virtues and moral superiority in an otherwise flawed system, and their discourses of blame displacement allowed them to underestimate their discretion and responsibility in the face of critiques of their power.

\section{Declaration of Conflicting Interests}

The authors declared no potential conflicts of interest with respect to the research, authorship, and/ or publication of this article.

\section{Funding}

The authors disclosed receipt of financial support for the research, authorship and/or publication of this article by the city government of "Belton".

\section{ORCID iD}

Alexandra L Cox (iD https://orcid.org/0000-0001-9939-078X 


\section{Notes}

1. Because we have anonymized the office that our findings are based on, we are not providing references to these sources which would reveal the name of the city where our study took place.

2. There are a few other criminal justice professions who elect their leaders, for example, sheriffs, who are elected in 42 US states.

3. In order to protect the confidentiality of the jurisdiction, we provide here a broad snapshot about where the jurisdiction lies in terms of its approach.

4. In a qualitative study of prosecutors in the Southern United States conducted by Levine and Wright (2017), the researchers also found that prosecutors frequently invoke their role as the "good guy" in the system.

5. Source intentionally omitted to maintain the confidentiality of interviewees and case study.

\section{References}

Akoensi TD and Tankebe J (2019) Prison officer self-legitimacy and support for rehabilitation in Ghana. Criminal Justice and Behavior 47: 22-38.

Barker R (2001) Legitimating Identities: The Self-Presentation of Rulers and Subjects. Cambridge: Cambridge University Press.

Bazelon E (2019) Charged: The New Movement to Transform American Prosecution and Transform Mass Incarceration. New York: Random House.

Beetham D (1991) The Legitimation of Power. Basingstoke: MacMillan.

Boltanski L and Thévenot L (1999) The sociology of critical capacity. European Journal of Social Theory 2: 359-377.

Bottoms A and Tankebe J (2013) 'A voice within': Power-Holders' perspectives on authority and legitimacy. In: Tankebe J and Liebling A (eds) Legitimacy and Criminal Justice: An International Exploration. Oxford: Oxford University Press.

Bottoms AE and Tankebe J (2012) Beyond procedural justice: A dialogic approach to legitimacy in crmiminal justice. Journal of Criminal Law and Criminology 102: 119-170.

Bourdieu P (1984) Distinction: A Social Critique of the Judgement of Taste. London: Routledge and Kegan Paul.

Bourdieu P (1977) Outline of a Theory of Practice. New York: Cambridge University Press.

Bourdieu P (1987) The force of Law: Toward a sociology of the juridical field. Hastings Law Journal 38: 814-853.

Bradford B and Quinton P (2014) Self-legitimacy, police culture and support for democratic policing in an English constabulary. The British Journal of Criminology 54: 1023-1046.

Campbell MC (2011) Politics, prisons, and Law enforcement: An examination of the emergence of "Law and order" politics in texas. Law \& Society Review 45: 631-665.

Carr N and Robinson G (2020) A legitimate business? Representations of privatised probation in England and Wales. Crime Media Culture 17(2): 235-254.

Chilton P (2003) Analysing Political Discourse, Theory and Practice. London: Routledge.

Coicaud J-M (2002) Legitimacy and Politics: A Contribution to the Study of Political Right and Political Responsibility. Cambridge: Cambridge University Press.

Côté-Lussier C (2013) Narratives of legitimacy: Police expansionism and the contest over policing. Policing and Society 23: 183-203.

Davis AJ (2005) The power and discretion of the American prosecutor. Droit et Cultures 49: 55-66.

Deering J and Feilzer M (2017) Questions of legitimacy in probation practice after transforming rehabilitation. The Howard Journal of Crime and Justice 56: 158-175.

Deterding NM and Waters MC (2018) Flexible coding of In-depth interviews: A twenty-first-century approach. Sociological Methods \& Research 50: 708-739. 
Foucault M (1980) Power/Knowledge: Selected Interviews and Other Writings 1972-1977, Brighton. Sussex: The Harvester Press.

Frohmann L (1991) Discrediting victims' allegations of sexual assault: Prosecutorial accounts of case rejections. Social Problems 38: 213-226.

Frohmann L (1997) Convictability and discordant locales: Reproducing race, class, and gender ideologies in prosecutorial decisionmaking. Law \& Society Review 31: 531-555.

Gagnon J and Richards C. (2008). Making the right turn: A guide about improving transition outcomes of youth involved in the juvenile corrections system. Washington, DC: National Collaborative on Workforce and Disability for Youth, Institute for Educational Leadership.

Harris D (2012) The interaction and relationship between prosecutors and police officers in the United States, and how this affects police reform efforts. In: Luna E and Wade M (eds) The Prosecutor in Transnational Perspective. Oxford: Oxford University Press.

Herbert S (2006) Tangled up in blue: Conflicting paths to police legitimacy. Theoretical Criminology 10: 481-504.

Howarth D (2000) Discourse. Buckingham: Open University Press.

Jackson RH (1940) The federal prosecutor. Journal of Criminal Law and Criminology (19311951) 31: 3-6.

Jonathan-Zamir T and Harpaz A (2014) Police understanding of the foundations of their legitimacy in the eyes of the public: The case of commanding officers in the Israel national police. The British Journal of Criminology 54: 469-489.

Levine KL and Wright RF (2017) Images and Allusions in Prosecutors' Morality Tales. Virginia Journal of Criminal Law 5: 38-67.

Martin R and Bradford B (2019) The anatomy of police legitimacy: Dialogue, power and procedural justice. Theoretical Criminology: 1362480619890605.

Mcevoy K (2019) Cause lawyers, political violence, and professionalism in conflict. Journal of Law and Society 46: 529-558.

Miller L (2008) The Perils of Federalism: Race, Poverty and the Politics of Crime Control. New York: Oxford University Press.

Miller ML (2004) Domination \& dissatisfaction: Prosecutors as sentencers. Stanford Law Review 56: $1211-1269$.

Pfaff J. 2017. Locked In: The True Causes of Mass Incarceration and How to Achieve Real Reform. New York: Basic Books.

Reus-Smit C (2007) International crises of legitimacy. International Politics 44(2): 157-174.

Simon J (2007) Governing Through Crime: How the War on Crime Transformed American Democracy and Created a Culture of Fear. New York: Oxford University Press.

Spohn C (2014) The non-prosecution of human trafficking cases: An illustration of the challenges of implementing legal reforms. Crime, Law and Social Change 61: 169-178.

Spohn C, Beichner D and Davis-Frenzel E (2001) Prosecutorial justifications for sexual assault case rejection: Guarding the "gateway to justice". Social Problems 48: 206-235.

Spohn C, Gruhl J and Welch S (1987) The impact of the ethnicity and gender of defendants on the decision to reject or dismiss felony charges*. Criminology; An Interdisciplinary Journal 25: 175-192.

Sklansky D (2016) The nature and function of prosecutorial power. Journal of Criminal Law and Criminology 106: 473-520.

Sklansky DA (2018) The problems with prosecutors. Annual Review of Criminology 1: 451-469.

Tajfel H. 1978. Differentiation Between Social Groups: Studies in the Social Psychology of Intergroup Relations. London: Academic Press.

Tankebe J (2010) Identifying the correlates of police organizational commitment in Ghana. Police Quarterly 13: 73-91. 
Tankebe J (2014) Rightful authority: Exploring the structure of police self-legitimacy. In: Liebling A, Shapland J and Tankebe J (eds) Crime, Justice and Social Order: Essays in Honour of A. E. Bottoms. Oxford: Oxford University Press.

Tankebe J (2019) In their own eyes: An empirical examination of police self-legitimacy. International Journal of Comparative and Applied Criminal Justice 43: 99-116.

Thumala A, Goold B and Loader I (2011) A tainted trade? Moral ambivalence and legitimation work in the private security industry1. The British Journal of Sociology 62: 283-303.

Trinkner R, Tyler TR and Goff PA (2016) Justice from within: The relations between a procedurally just organizational climate and police organizational efficiency, endorsement of democratic policing, and officer well-being. Psychology, Public Policy, and Law 22: 158-172.

Turner J and Redlich A (2016) Two models of Pre-plea discovery in criminal cases: An empirical comparison. Washington and Lee Law Review 73: 285-408.

Tyler JR and Jackson J (2013) Future challenges in the study of legitimacy and criminal justice. In: Tankebe J and Liebling A (eds) Legitimacy and Criminal Justice: An International Exploration. Oxford: Oxford University Press.

Tyler TR (1990) Why People Obey the Law. New Haven: Connecticut, Yale University Press.

Tuesta D (2021) Rethinking prosecutorial discretion: Towards A moral cartography of prosecutors. The British Journal of Criminology 61: 1486-1502.

Van Dijk TA (1995) Discourse semantics and ideology. Discourse \& Society 6: 243-289.

Weber M (1914) Economy and Society: An Outline of Interpretive Sociology. London: University of California Press.

Wright M, Baughman SB, Shima Baradaran S and Robertson C. (Forthcoming) Inside the Black Box of Prosecutor Discretion. UC Davis Law Review, Penn State Law Research Paper No. 19-2021, University of Utah College of Law Research Paper No. 459, Available at SSRN: https://ssrn.com/abstract=3893820. 